University of Nebraska - Lincoln

DigitalCommons@University of Nebraska - Lincoln

Biological Systems Engineering: Papers and

Publications

Biological Systems Engineering

2006

\title{
Postharvest treatment to control codling moth in fresh apples using water assisted radio frequency heating
}

\author{
Shaojin Wang \\ Washington State University, shaojin_wang@wsu.edu \\ Sohan Birla \\ University of Nebraska-Lincoln, sbirla2@unl.edu \\ J. D. Hansen \\ USDA ARS Yakima Agricultural Research Laboratory, jimbob@yarl.ars.usda.gov
}

Follow this and additional works at: https://digitalcommons.unl.edu/biosysengfacpub

Part of the Biological Engineering Commons

Wang, Shaojin; Birla, Sohan; and Hansen, J. D., "Postharvest treatment to control codling moth in fresh apples using water assisted radio frequency heating" (2006). Biological Systems Engineering: Papers and Publications. 209.

https://digitalcommons.unl.edu/biosysengfacpub/209

This Article is brought to you for free and open access by the Biological Systems Engineering at DigitalCommons@University of Nebraska - Lincoln. It has been accepted for inclusion in Biological Systems Engineering: Papers and Publications by an authorized administrator of DigitalCommons@University of Nebraska Lincoln. 


\title{
Postharvest treatment to control codling moth in fresh apples using water assisted radio frequency heating
}

\author{
S. Wang ${ }^{\text {a }}$, S.L. Birla ${ }^{\text {a }}$, J. Tang ${ }^{\text {a,* }}$, J.D. Hansen ${ }^{\mathrm{b}}$ \\ ${ }^{a}$ Department of Biological Systems Engineering, Washington State University, 213 L.J. Smith Hall, \\ Pullman, WA 99164-6120, USA \\ ${ }^{\mathrm{b}}$ USDA ARS Yakima Agricultural Research Laboratory, 5230 Konnowac Pass Road, Wapato, WA 98951, USA
}

Received 30 July 2005; accepted 9 December 2005

\begin{abstract}
Apples destined for export to Japan and South Korea are currently disinfested for codling moth, Cydia pomonella L. (Lepidoptera: Tortricidae), using methyl bromide fumigation. Restrictions and limitations imposed on the uses of methyl bromide have increased interest in developing alternative non-chemical quarantine treatments. It is imperative that the treatment is effective against codling moth yet maintains the quality of treated apples. The present study explored the application of radio frequency (RF) energy in conjunction with conventional hot water treatment to develop feasible heat treatments. Treatment parameters were selected based on minimum time-temperature conditions required for $100 \%$ mortality of fifth-instar codling moth and apple quality. The treatments included preheating of infested or wholesome apples in warm water at $45^{\circ} \mathrm{C}$ for $30 \mathrm{~min}$. The preheated apples were then heated to $48^{\circ} \mathrm{C}$ in a hydraulic fruit mover placed between two parallel plate electrodes in a $12 \mathrm{~kW}, 27.12 \mathrm{MHz}$ pilot scale RF system. RF treated apples were transferred to a $48^{\circ} \mathrm{C}$ hot water bath and held for 5, 10, 15 and $20 \mathrm{~min}$ before being hydro-cooled in ice water for $30 \mathrm{~min}$. The mortality of codling moths in the infested apples was assessed, and the quality of wholesome apples was evaluated by measuring weight loss, firmness, color, soluble solids content, and titratable acidity after 0,7 , and 30 days of storage at $4{ }^{\circ} \mathrm{C}$. The results showed that the treatment at $48^{\circ} \mathrm{C}$ for 15 min was the most practical and effective both for insect control and apple quality.
\end{abstract}

(C) 2005 Elsevier B.V. All rights reserved.

Keywords: Apple; Codling moth; Heat; Quality; Quarantine; Radio frequency

\section{Introduction}

The export of fresh apples in the United States is mainly destined for Japan and South Korea (USDANASS, 2004). These countries require quarantine treatments against codling moth, Cydia pomonella L. (Lepidoptera: Tortricidae). Methyl bromide (MeBr) is used in commercial treatments against codling moth in fresh products (Guance et al., 1981; Yokoyama et al., 1990; Moffitt et al., 1992; Hansen et al., 2000). Although MeBr fumigation for postharvest quarantine treatments is currently exempt from legal restrictions, the future for $\mathrm{MeBr}$

\footnotetext{
* Corresponding author. Tel.: +1 509335 2140; fax: +1 5093352722 .

E-mail address: jtang@mail.wsu.edu (J. Tang).
}

usage is questionable because of price increases, complicated approval process of the exempted use, and further restrictions under international regulations (USEPA, 1998). Therefore, there is a need to develop non-chemical quarantine treatment alternatives for international trade of apples.

Heat treatments are studied in laboratories to disinfest fresh horticultural products from quarantine pests, such as codling moth and fruit flies, before entering exportmarketing channels (Armstrong, 1994; Feng et al., 2004; Hansen et al., 2004). Some heat treatments have been approved by the USDA Animal Plant Health Inspection Service as quarantine treatments against the eggs and larvae of targeted fruit fly pests in a number of tropical fruit, including mango, citrus and papaya (USDA-APHIS$P P Q, 2002)$. Heat treatments are relatively easy to apply, 
leave no chemical residues, and can be fungicidal. However, accomplishing disinfestation without causing deleterious effects to fruit quality is a challenging task (Armstrong, 1994). In conventional heating with water or air, the rate of thermal energy delivered to the interior of the commodities is significantly influenced by fruit size (Wang et al., 2001b). Fresh fruit are sensitive to heat and often a slight deviation from the required time and temperature would result in either unacceptable fruit quality or insect survival.

To shorten treatment time and, thereby, minimize thermal impact on fruit quality, radio frequency (RF) heating has been suggested for control of postharvest insects (Andreuccetti et al., 1994; Hallman and Sharp, 1994; Nelson, 1996; Tang et al., 2000). Recently, pilot-scale RF treatment protocols have been developed for control of codling moth (Wang et al., 2001a) and navel orangeworm (Wang et al., 2002b; Mitcham et al., 2004) in in-shell walnuts with acceptable product quality. A joint university and industry project in summer 2005 that involved scientists and engineers from Washington State University, University of California, Davis, US Department of Agriculture, Strayfield Fastran Inc. (UK), and Diamond Walnut Co. (Stockton, CA) has successfully demonstrated that large commercial continuous RF treatments can be designed based on pilot-scale protocols to effectively control navel orangeworm, the most heat resistant field and storage pests among codling moth, Indian meal both and red flour beetle (Johnson et al., 2004), in in-shell walnuts without causing quality losses.

It is also desirable to explore the possibility of developing a short time pilot-scale heat treatment for disinfesting apples using RF energy. To avoid overheating at the contact points between fresh fruit, water immersion is used in RF heating (Ikediala et al., 2002; Birla et al., 2004). That is, fresh fruit are immersed in tap water while heated in RF systems. Since dielectric loss factors of fresh fruit are higher than those of tap water at the RF range (Wang et al., 2003), the fruit may absorb much more RF energy than the tap water, thus resulting in different heating rates. A corefocus heating in fresh fruit is observed in RF heated fruit in tap water (Ikediala et al., 2002; Birla et al., 2004). Matching electrical conductivity of the water with that of fruit pulp may help to improve the non-uniformity between the surface and the core (Birla et al., 2004). But the observed heating uniformity is not adequate to allow the development of a practical treatment for insect control in apples and oranges without causing significant quality damage. Core heating by RF energy can be compensated with surface heating using hot water to provide more uniform final temperature distribution in fruit.

The objectives of this study were to determine the process parameters for hot water assisted RF treatment, to investigate the effectiveness of RF thermal treatments against codling moth in apples, and to evaluate the postharvest quality of treated apples.

\section{Materials and methods}

\subsection{Sample preparations}

For efficacy tests, 'Red Delicious' apples (size, 80; diameter, $8.0 \pm 0.1 \mathrm{~cm}$; weight, $266 \pm 2 \mathrm{~g}$ ) were procured from a packaging house located in Yakima, WA. Codling moth larvae were reared at the USDA ARS Yakima Agricultural Research Laboratory (YARL) in Wapato, WA. The larvae colony was fed on a soy-wheat germ-starch artificial diet at $27^{\circ} \mathrm{C}, 40-58 \% \mathrm{RH}$, and 16:8 $\mathrm{h}$ light:dark photoperiod (Toba and Howell, 1991). The insects were shipped from YARL to Washington State University (WSU) (Pullman, WA) by overnight delivery for RF and hot water treatments. Since the fifth-instars were the most heat tolerant stage of the codling moth (Yokoyama et al., 1991; Wang et al., 2002a, 2004), late fourth to early fifth-instars were removed from the artificial diet and used for artificial infestation of apples. Seven apples and 35 larvae per replicate were enclosed in a single ventilated plastic container. The containers were held at $22^{\circ} \mathrm{C}, 60-70 \% \mathrm{RH}$, and $16: 8 \mathrm{~h}$ light:dark photoperiod for an additional 2 days to allow the larvae to infest the apples and develop into fifth-instars before heat treatments.

Freshly harvested 'Red Delicious' apples (size, 80; diameter, $8.0 \pm 0.1 \mathrm{~cm}$; weight, $266 \pm 2 \mathrm{~g}$ ) were procured from a local orchard (Pullman, WA) for quality evaluation.

\subsection{RF heating system description and treatment procedure}

Apples were stored at room temperature for more than $24 \mathrm{~h}$ at WSU prior to the scheduled heat treatments. A preliminary experiment was conducted with nine apples in each test to determine the temperature-time history of apple sub-surface and core temperatures, as well as the heating uniformity at various stages of the heat treatment process. Two apples were taken out after water preheating in a water bath (Model ZD, Grant, Cambridge, UK) and seven went through RF heating in a hydraulic fruit mover. During the preheating, two thin thermocouples (Type-T, THQSS-020U-6, Omega Engineering Inc., Stamford, CT) were inserted into a randomly selected apple at about $2 \mathrm{~mm}$ (sub-surface) and $40 \mathrm{~mm}$ (core) below the skin, respectively. The apple sub-surface and core temperatures were recorded by a data logger (DL2e, Delta-T Devices Ltd., Cambridge, UK) with a time interval of $10 \mathrm{~s}$ during the water preheating, holding and hydro-cooling processes (Fig. 1). Continuous temperature recording during RF heating was not possible due to the movement and rotation of fruit in the water medium. RF heating temperature profiles were estimated by the temperatures between the end of water preheating and the beginning of holding using a linear interpolation. At the end of each treatment stage, two apples were randomly selected and removed for recording of the thermal imaging of two cut cross sections, one perpendicular to the apple stem and another one along the stem. The thermal images were taken with an infra-red imaging 


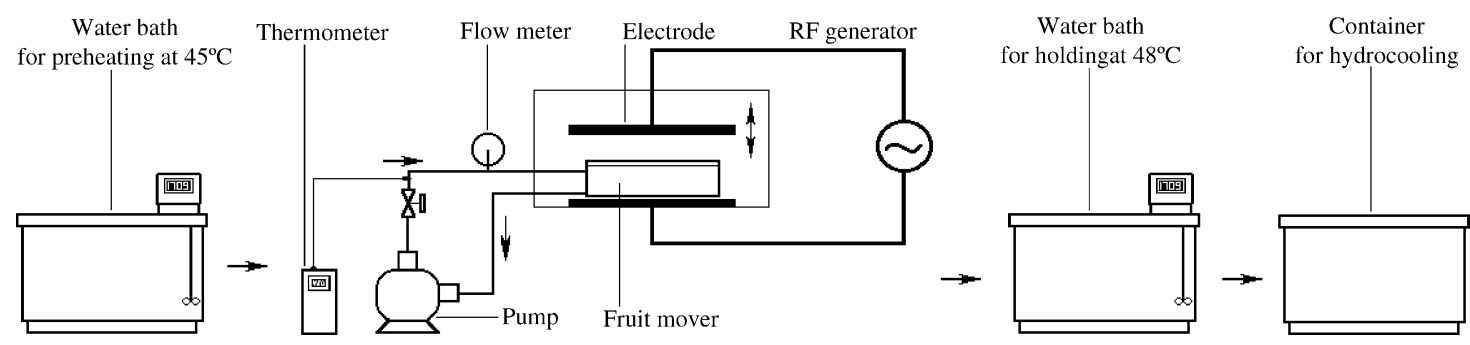

Fig. 1. Schematic view of the water assisted RF treatment process.

camera (ThermaCAM ${ }^{\mathrm{TM}}$ Researcher 2001, accuracy $\pm 2{ }^{\circ} \mathrm{C}$, FL-IR Systems, Portland, OR). Five seconds were required for each complete imaging process. To reduce the heat loss from the apple surface when the thermal image was taken, the half apple facing the camera was surrounded with water at the treatment temperature. In each of the thermal images, $168 \times 168$ individual temperature data were collected over the whole image and about 19,600 points for the targeted area of apples were used for contour plots and statistical analyses.

For each RF heating experiment, seven randomly selected fresh apples were preheated in a circulating hot water bath at $45^{\circ} \mathrm{C}$ water for $30 \mathrm{~min}$ (Fig. 1). The preheated apples were transferred into a hydraulic fruit mover developed in our laboratory specifically for $\mathrm{RF}$ treatment. The fruit mover provides for a three-dimensional rotation of the fruit by means of 12 Teflon water spray nozzles mounted on the periphery of the container, which help to rotate fruit on their axes and in a circular path. Details of the fruit mover and its operating procedure can be found elsewhere (Birla et al., 2004). The fruit mover container was filled with $45^{\circ} \mathrm{C}$ tap water and placed between two electrodes of a $27.12 \mathrm{MHz}$ and $12 \mathrm{~kW}$ batch type RF heating system (Strayfield Fastran with E-200, Strayfield International Limited, Wokingham, UK). RF power was set at $6 \mathrm{~kW}$ and water temperature was monitored by the thermocouples in the circulation pipe outside of the RF unit during the RF heating process. The RF power was switched off once the water temperature reached $48^{\circ} \mathrm{C}$.

$\mathrm{RF}$ heated apples were removed from the fruit mover and transferred to a hot water bath maintained at $48^{\circ} \mathrm{C}$ (Fig. 1). The selection of the $48^{\circ} \mathrm{C}$ treatment temperature was based on the reported quality of papaya after vapor heating at $47.8^{\circ} \mathrm{C}$ for $4 \mathrm{~h}$ (Hayes et al., 1984; Shellie and Mangan, 2000) and oranges at $48^{\circ} \mathrm{C}$ for $15 \mathrm{~min}$ (Birla et al., 2005). The holding time was chosen based on the time $(15 \mathrm{~min})$ required to achieve $100 \%$ mortality of 600 fifth-instars of codling moth determined by the heating block system (Wang et al., 2002a). For efficacy tests, two unheated samples were used as controls where one kept in air and the other in water, both at room temperature for $80 \mathrm{~min}$. The treatments included water preheating at $45^{\circ} \mathrm{C}$ for $30 \mathrm{~min}$, and RF heating to $48^{\circ} \mathrm{C}$ and holding at $48^{\circ} \mathrm{C}$ water for $5,10,15$, and 20 min after the water preheating at $45^{\circ} \mathrm{C}$ for $30 \mathrm{~min}$ and prior to hydro-cooling in ice water for $30 \mathrm{~min}$. The hydro-cooled apples were packed again in ventilated containers and stored at room temperature. For apple quality tests, the three relatively long holding times
(10, 15 and $20 \mathrm{~min}$ ) were used for the three heat treatments followed by the same procedure for the water preheating, the RF heating and the hydro-cooling as the efficacy tests. The hydro-cooled apples were divided into two groups for each treatment combination. A surface coating of Carnuaba natural wax was applied to one group (seven apples) before storage at $4{ }^{\circ} \mathrm{C}$. A group of untreated apples, control both waxed and unwaxed were also stored with the treated apples. All tests were repeated three times.

\subsection{Insect mortality and quality evaluation}

Efficacy of heat treatments was evaluated the following day. For each treatment, infested apples were carefully dissected and observed for any live larvae and for number of dead larvae. Average and standard deviation values of insect morality were calculated from three replicates of seven apples for each treatment.

Postharvest quality, including weight loss, firmness, peel and pulp color, soluble solids, and titratable acidity (TA), was measured before heat treatment and after 7 and 30 days storage at $4{ }^{\circ} \mathrm{C}$ after the treatment. Weight loss was expressed as percentage of weight lost from the initial weight. The firmness at three marked locations along the equatorial fruit surface was measured by a Texture Analyzer (Model TAXT2, Stable Micro Systems, YL, UK). The fruit was held in position on a concave shaped Nylon disc during firmness measurements. Firmness was expressed as a maximum force in newtons $(\mathrm{N})$ required to penetrate the $11 \mathrm{~mm}$ probe $8 \mathrm{~mm}$ deep into the apple with $400 \mathrm{~mm} / \mathrm{min}$ cross head speed. Prior to measuring firmness, the marked spots were peeled. Peel and pulp colors were measured at three marked spots on an individual apple by a colorimeter (Model CM-2002, Minolta Corp., Ramsey, NJ) calibrated to a standard white reflective plate. The color was expressed in terms of $L^{*}, C^{*}, h^{\circ}$ color system $\left(L^{*}\right.$, darkness; $C^{*}$, chroma; $h^{\circ}$, hue angle). Total soluble solids and percent TA were measured for control apples upon receiving and for heat-treated apples at 7 and 30 days storage at $4{ }^{\circ} \mathrm{C}$. Six apples from each treatment were used for preparation of composite juice samples. TA of the samples was determined by end-point titration of $5 \mathrm{ml}$ juice sample to $\mathrm{pH} 8.2$ with $0.1 \mathrm{~N} \mathrm{NaOH}$ solution. TA is expressed in terms of the equivalent anhydrous malic acid in $\mathrm{g} / 100 \mathrm{ml}$ of juice. Total soluble solids (TSS, ${ }^{\circ}$ Brix) was measured using a handheld refractometer (Model N-1 $\alpha$, ATAGO Co. Ltd., Tokyo) 
with a sucrose scale calibrated at $20^{\circ} \mathrm{C}$ and expressed as percent soluble solids.

The measured values for individual quality attributes were subjected to a factorial analysis of variance (ANOVA) (GLM procedure, SAS Institute, 1990, Cary, NC) with storage time, wax coating, and treatment as main effects. Means were separated using Tukey's method of multiple pair-wise comparisons.

\section{Results and discussion}

\subsection{Temperature distributions of apples}

Fig. 2 shows a typical temperature-time history at the core and sub-surface of 'Red Delicious' apples $\left(22^{\circ} \mathrm{C}\right.$ initial temperature) subjected to water preheating, RF heating, holding at $48{ }^{\circ} \mathrm{C}$ and hydro-cooling. After $30 \mathrm{~min}$ water preheating at $45^{\circ} \mathrm{C}$, apple core and sub-surface $(2 \mathrm{~mm}$ below the surface) temperatures reached 39 and $45^{\circ} \mathrm{C}$, respectively. After $1.25 \mathrm{~min}$ of $\mathrm{RF}$ heating in $45^{\circ} \mathrm{C}$ tap water with $6 \mathrm{~kW}$ input RF power, the core and sub-surface temperatures reached 48 and $47^{\circ} \mathrm{C}$, respectively. Holding of the apples in hot water at $48^{\circ} \mathrm{C}$ for a certain time period (e.g. $10 \mathrm{~min}$ ) ensured a relatively uniform temperature profile over the entire apple cross section and provided an accumulation of thermal lethality of codling moth larvae. Hydro-cooling with $1{ }^{\circ} \mathrm{C}$ water of heat treated apples expedited the cooling rate as the core temperature dropped from 48 to $19^{\circ} \mathrm{C}$ in $30 \mathrm{~min}$ (Fig. 2). The contour plots from thermal images of apples recorded at the end of water preheating, RF heating, holding and hydro-cooling are shown in Fig. 3. Preheating in hot water established a temperature gradient from the surface $\left(44^{\circ} \mathrm{C}\right)$ to the core $\left(36^{\circ} \mathrm{C}\right)$. Those two temperatures were close to those measured by thermocouples. As demonstrated in the preliminary RF heating experiment, RF heating has a core-focused heating of apples. Therefore, using preheated apples in RF assisted heating treatments resulted in a fairly uniform temperature $\left(47.3 \pm 0.7^{\circ} \mathrm{C}\right)$ in fruit (Fig. 3b). The water preheating of

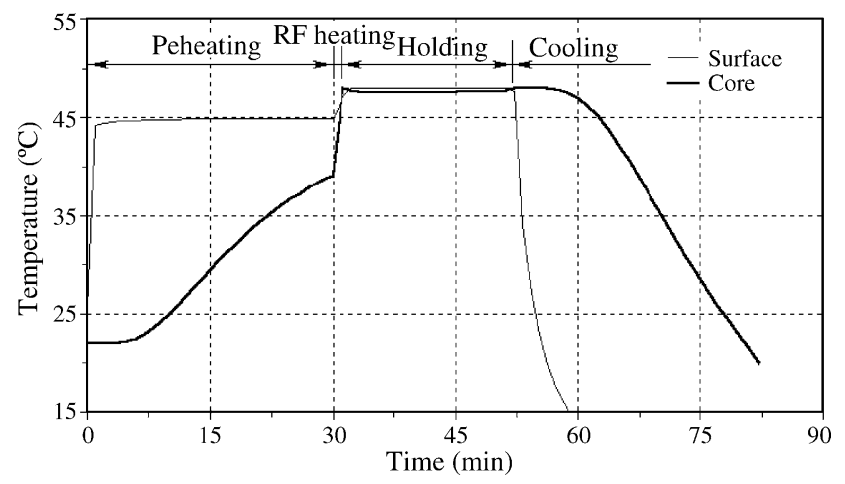

Fig. 2. Typical time-temperature history for surface and core of "Red Delicious" apples (diameter, $8 \mathrm{~cm}$ ) when subjected to water preheating $\left(45^{\circ} \mathrm{C}\right.$, $1 \mathrm{~m} / \mathrm{s})$, RF heating $(27.12 \mathrm{MHz}, 6 \mathrm{~kW})$ for $1.25 \mathrm{~min}$, holding in a hot water bath $\left(48^{\circ} \mathrm{C}, 1 \mathrm{~m} / \mathrm{s}\right)$ for $20 \mathrm{~min}$, and $30 \mathrm{~min}$ hydro-cooling. apples also reduced the RF process time required to raise the fruit temperature to $48^{\circ} \mathrm{C}$. The RF heating took only $1.25 \mathrm{~min}$ to bring overall temperature of preheated apples from 45 to $48^{\circ} \mathrm{C}$. There were no drops of temperature at the apple surface when using the water to immerse apples. The apple surface temperature achieved $48^{\circ} \mathrm{C}$ after RF heating. Some small hot spots $\left(50^{\circ} \mathrm{C}\right)$ along the stem and close to the air cavity and clod spots $\left(44^{\circ} \mathrm{C}\right)$ near the sub-surface were found (Fig. 3b). Holding RF heated apples in hot water at $48^{\circ} \mathrm{C}$ for $10 \mathrm{~min}$ further reduced the temperature gradient and improved temperature uniformity (Fig. 3c). The mean temperature over the apple horizontal cross section was $47.1 \pm 1.0$ and $47.3 \pm 0.7^{\circ} \mathrm{C}$ before and after holding, respectively. The temperature uniformity in apples was better for those treated with RF assisted hot water heating than that of apples RF heated in matched saline solution in a fruit mover $\left(53.6 \pm 4.8^{\circ} \mathrm{C}\right)$ (Birla et al., 2004). After the hydro-cooling for $30 \mathrm{~min}$, the core and surface temperatures dropped to 18 and $4{ }^{\circ} \mathrm{C}$, respectively (Fig. 3d). Therefore, water preheating of apples was useful in reducing RF heating time and in overcoming the limitations imposed by RF heating of fresh fruit.

\subsection{Treatment confirmation studies with infested apples}

Percent insect mortality (mean \pm S.D.) in unheated control apples was $5.7 \pm 2.9 \%$ and $8.6 \pm 2.9 \%$ for room temperature holding in air and water, respectively (Table 1). In general, mortality of fifth-instars in the control group was still low, suggesting that the effect of handling and shipment on mortality was negligible. Table 1 also shows the total numbers of live and dead codling moth larvae found in the heat-treated apples. After the water preheating at $45^{\circ} \mathrm{C}$ for $30 \mathrm{~min}$, the insect mortality was $19.1 \%$, suggesting some minor heat effect at $45^{\circ} \mathrm{C}$. With the RF treatment, the insect mortality increased to 97.1 and $98.1 \%$ after 5 and 10 min holding, respectively. These mortality values were higher or comparable to $70.2 \pm 11.8 \%$ and $97.4 \pm 0.5 \%$ at $48{ }^{\circ} \mathrm{C}$ for 5 and 10 min determined for fifth-instar codling moth using a heat block system (Wang et al., 2004). It took at least $15 \mathrm{~min}$ holding at $48^{\circ} \mathrm{C}$ in the water bath to ensure the death of all larvae. These results agreed with the thermal death kinetic studies on the fifth-instar codling moth using a heat block system (Wang et al., 2002a) and the infested studies in cherries (Hansen et al., 2004).

\subsection{Apple quality}

Table 2 shows the results of factorial ANOVA analysis performed on individual quality attributes, namely weight loss, firmness, and peel and pulp color. In presence of significant interactions among all factors, multiple pair-wise comparisons were performed to separate the main effects of individual factors on each quality attribute. The means listed in Table 2 for a specific factor (e.g. storage) were calculated from the measured data over the tested range of the other two factors (e.g. coating and treatment). These values summarize overall effects of each factor. 
(a)
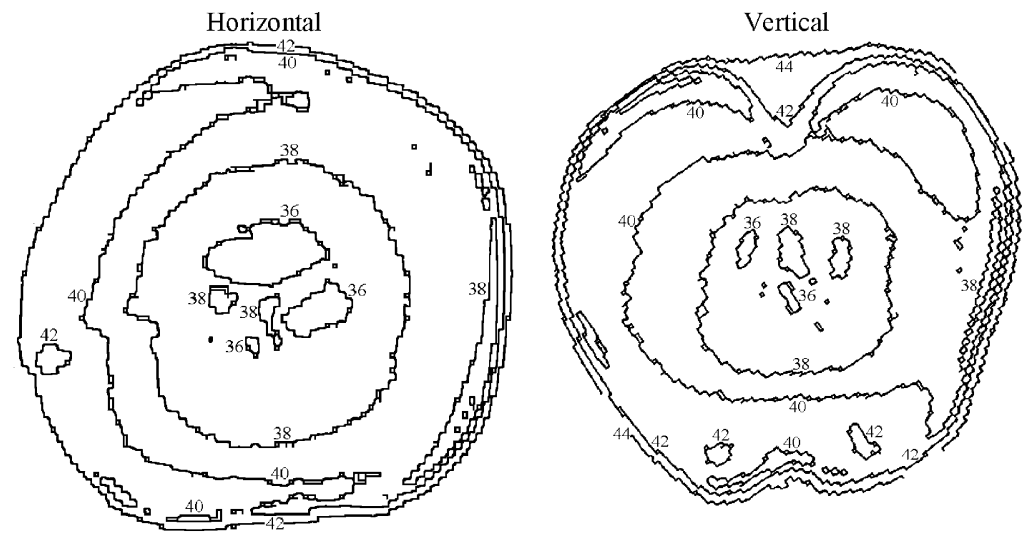

(b)
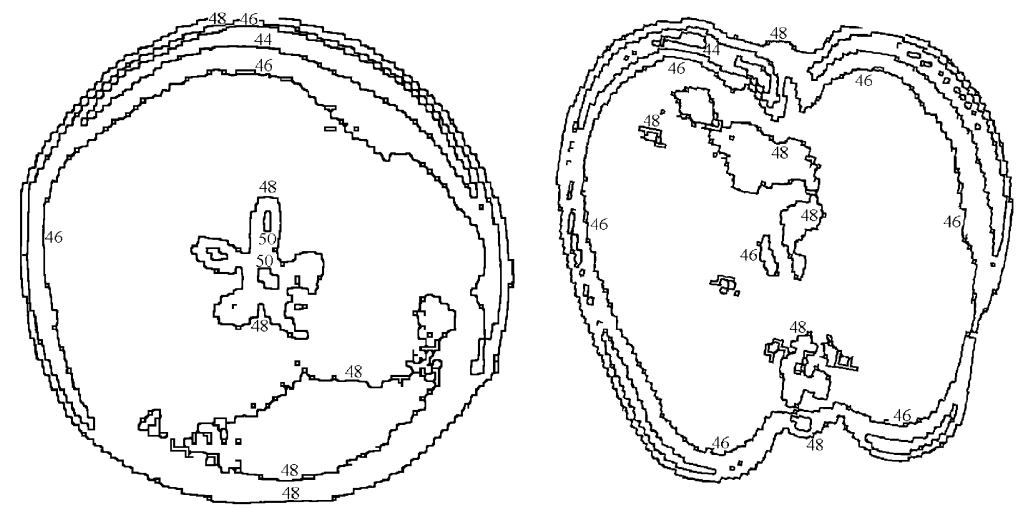

(c)
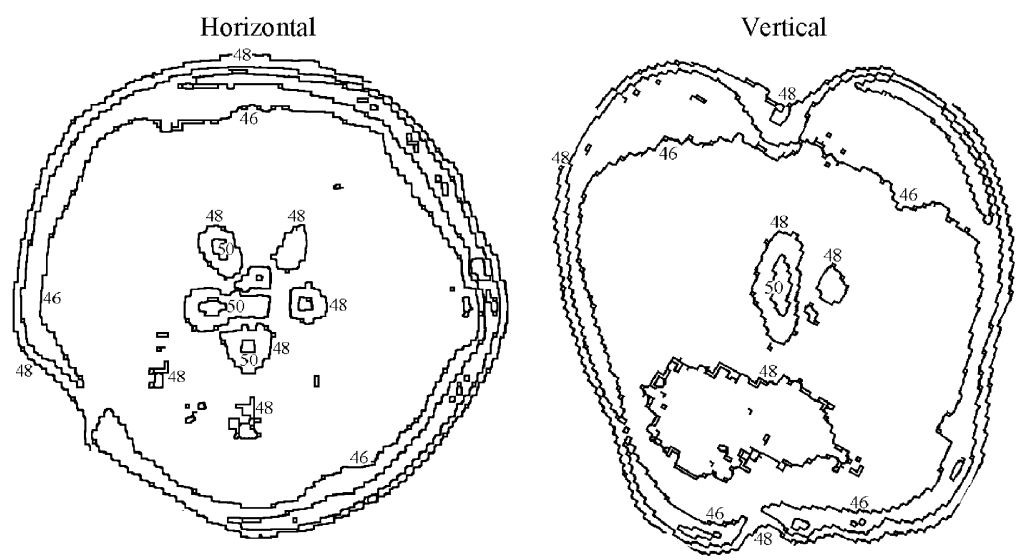

(d)

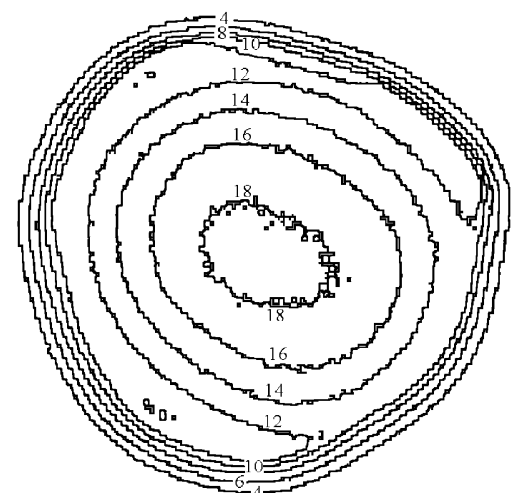

Fig. 3. Contour plot of temperature distribution obtained by thermal imaging over horizontal and vertical apple cross sections after: (a) water preheating at $45^{\circ} \mathrm{C}$ for $30 \mathrm{~min}$, (b) $\mathrm{RF}$ heating from 45 to $48^{\circ} \mathrm{C}$, (c) holding $10 \mathrm{~min}$ at $48^{\circ} \mathrm{C}$ water, and (d) hydro-cooling for $30 \mathrm{~min}$. 
Table 1

Total number of live and dead fifth-instar codling moths recovered from 'Red Delicious' apples with the mortality (mean \pm S.D., \%) over three replicates when subjected to the controls at room air and water and three treatments with the same water preheating $\left(45^{\circ} \mathrm{C}\right.$ for $\left.30 \mathrm{~min}\right)$, RF heating $(27 \mathrm{MHz}$ and $6 \mathrm{~kW}$ for $1.25 \mathrm{~min}$ ), and hydro-cooling for $30 \mathrm{~min}$ (three replicates with five larvae per apple)

\begin{tabular}{llcc}
\hline $\begin{array}{l}\text { Temperature }+ \\
\text { holding time }\end{array}$ & $\begin{array}{l}\text { Total number } \\
\text { of alive }\end{array}$ & $\begin{array}{l}\text { Total number } \\
\text { of dead }\end{array}$ & Mortality (\%) \\
\hline $\begin{array}{l}\text { Control at room air } \\
\text { Control at room }\end{array}$ & 99 & 6 & $5.7 \pm 2.9$ \\
$\quad 96$ & 9 & $8.6 \pm 2.9$ \\
$\quad$ water for 80 min & & & \\
$45^{\circ} \mathrm{C}+30 \mathrm{~min}$ & 85 & 20 & $19.1 \pm 8.7$ \\
$48^{\circ} \mathrm{C}+5 \mathrm{~min}$ & 3 & 102 & $97.1 \pm 2.9$ \\
$48^{\circ} \mathrm{C}+10 \mathrm{~min}$ & 2 & 103 & $98.1 \pm 1.7$ \\
$48^{\circ} \mathrm{C}+15 \mathrm{~min}$ & 0 & 105 & $100 \pm 0$ \\
$48^{\circ} \mathrm{C}+20 \mathrm{~min}$ & 0 & 105 & $100 \pm 0$ \\
\hline
\end{tabular}

\subsubsection{Weight loss}

Table 2 shows that two-way and three-way interactions among treatment factors were significant. Therefore, the main effects of wax coating, storage time and different treatments on the weigh loss were deducted from the pair-wise comparisons. Weight loss in unwaxed apples was significantly higher $(1.2 \%)$ than that of waxed apples $(0.82 \%)$. The RF heat treatments caused a significant lower weight loss from the apples in comparison with control apples. However increase in holding time after RF heating from 10 to 20 min resulted in increased weight loss. The reduced weight loss in the treated apples might be caused by the inhibition of ethylene produc- ing enzymes or heat induced redistribution of natural wax on the apple skin. Ethylene is commonly known to be responsible for the acceleration of fruit ripening. If this is true, the heat treatment may also be good for long-term storage of apples. To corroborate this, more heat treatments should be performed to determine the overall effects of heat on the quality during extended storage time.

\subsubsection{Firmness}

The effect of wax coating on firmness was not significant; however storage time and RF treatments significantly influenced the firmness. The mean firmness upon 30 days of storage of all apples at $4{ }^{\circ} \mathrm{C}$ was reduced from a value of 79.5 measured before treatments to $71.25 \mathrm{~N}$ (Table 2). The firmness of RF treated apples was significantly higher than that of the control apples. This may be due to the inhibition of ethylene producing enzyme and reducing the rate of respiration. Decreased respiration translates to a reduced consumption of fruit sugars and decreased water loss during storage. This was supported by the weight loss results, which showed that heattreated apples lost a significantly lower amount of weight as compared to the untreated apples. The effect of the wax coating on firmness was not significant.

\subsubsection{Fruit color}

Table 2 shows the analysis of apple peel color change in terms of value $\left(L^{*}\right)$, hue $\left(h^{\circ}\right)$ and chroma $\left(C^{*}\right)$. A decreased value of $L^{*}$ indicated a shift of color toward darker or gray

Table 2

Mean squares and mean values for quality attributes of 'Red Delicious' apples subjected to RF heat treatments

\begin{tabular}{|c|c|c|c|c|c|c|c|c|c|}
\hline \multirow[t]{2}{*}{ Source } & \multirow[t]{2}{*}{ d.f. } & \multirow[t]{2}{*}{ Weight loss (\%) } & \multirow[t]{2}{*}{ Firmness (N) } & \multicolumn{3}{|l|}{ Peel color } & \multicolumn{3}{|l|}{ Pulp color } \\
\hline & & & & $L^{*}$ & $h^{\circ}$ & $C^{*}$ & $L$ & $h^{\circ}$ & $C^{*}$ \\
\hline \multicolumn{10}{|l|}{ Mean squares } \\
\hline Waxed (W) & 1 & $1521.67^{*}$ & 5.97 & 48.64 & $390.71^{*}$ & $599.69^{*}$ & 109.47 & 0.015 & $82.21^{*}$ \\
\hline Storage time (ST) & 1 & $12522.56^{*}$ & $1370.65^{*}$ & 44.24 & $312.63^{*}$ & $233.75^{*}$ & 27.81 & 23.479 & 5.88 \\
\hline Treatment $(\mathrm{T})$ & 3 & $4174.86^{*}$ & $1204.24^{*}$ & 49.78 & $151.51^{*}$ & $601.05^{*}$ & $460.89^{*}$ & $36.09^{*}$ & $85.87^{*}$ \\
\hline $\mathrm{W} \times \mathrm{ST}$ & 1 & $882.36^{*}$ & 1.99 & 0.53 & 2.9 & 5.22 & 79.77 & $27.96^{*}$ & 8.29 \\
\hline $\mathrm{W} \times \mathrm{T}$ & 3 & $114.99^{*}$ & 98.16 & 5.83 & 6.41 & 8.98 & 47.78 & $20.04^{*}$ & $160.66^{*}$ \\
\hline $\mathrm{ST} \times \mathrm{T}$ & 3 & $2145.05^{*}$ & $312.34^{*}$ & 14.48 & 34.76 & 17.32 & $265.07^{*}$ & 2.25 & $142.24^{*}$ \\
\hline $\mathrm{W} \times \mathrm{ST} \times \mathrm{T}$ & 3 & $30.03^{*}$ & 68.82 & 30.02 & 199.13 & 35.88 & $400.76^{*}$ & $27.31^{*}$ & $82.57^{*}$ \\
\hline Error (d.f.) & & $0.0011(32)$ & 92.27 (173) & $14.42(352)$ & 36.15 & $26.06(352)$ & $59.75(266)$ & $6.7(266)$ & $16.07(266)$ \\
\hline \multicolumn{10}{|l|}{ Means $\#$} \\
\hline \multicolumn{10}{|l|}{ Waxed } \\
\hline Yes & & $0.82 \mathrm{a}^{+}$ & 74.28 & 31.63 & $23.45 b$ & $24.63 b$ & 69.61 & 87.45 & $22.03 \mathrm{~b}$ \\
\hline No & & $1.20 \mathrm{~b}$ & 73.91 & 32.68 & $21.34 \mathrm{a}$ & $22.02 \mathrm{a}$ & 68.32 & 87.44 & 20.91a \\
\hline \multicolumn{10}{|l|}{ Storage (days) } \\
\hline 7 & & $0.46 a$ & $76.94 b$ & 31.65 & $21.45 \mathrm{a}$ & $22.51 \mathrm{a}$ & 69.29 & 87.75 & 21.62 \\
\hline 30 & & $1.56 \mathrm{~b}$ & $71.25 \mathrm{a}$ & 32.36 & $23.34 \mathrm{~b}$ & $24.14 b$ & 68.64 & 87.15 & 21.32 \\
\hline \multicolumn{10}{|l|}{ Treatment } \\
\hline Control & & $1.93 \mathrm{~d}$ & $65.71 \mathrm{a}$ & 32.7 & $23.05 \mathrm{ab}$ & $27.02 \mathrm{c}$ & $72.25 b$ & $88.52 b$ & $22.46 b$ \\
\hline $48^{\circ} \mathrm{C}+10 \mathrm{~min}$ & & $0.52 \mathrm{a}$ & $76.00 \mathrm{~b}$ & 32.61 & $23.66 \mathrm{~b}$ & $23.71 \mathrm{~b}$ & $66.59 \mathrm{a}$ & $87.07 \mathrm{a}$ & $20.71 \mathrm{ab}$ \\
\hline $48^{\circ} \mathrm{C}+15 \mathrm{~min}$ & & $0.75 b$ & $77.81 \mathrm{~b}$ & 31.16 & $22.32 \mathrm{ab}$ & $20.82 \mathrm{a}$ & $67.07 \mathrm{a}$ & $87.28 \mathrm{a}$ & $20.29 a$ \\
\hline $48^{\circ} \mathrm{C}+20 \mathrm{~min}$ & & $0.84 \mathrm{c}$ & $76.85 b$ & 31.55 & $20.56 \mathrm{a}$ & $21.74 \mathrm{a}$ & $69.94 \mathrm{ab}$ & $86.92 \mathrm{a}$ & $22.4 \mathrm{~b}$ \\
\hline
\end{tabular}

\footnotetext{
* Main effects and interactions are significant at $P<0.05$; d.f., degree of freedom.

${ }^{+}$Means with different letters are significantly different at $P<0.05$.

\# Means for a factor were calculated from the measured data over the tested range of the other two factors.
} 
side on the scale of light to dark ( 0 for dark and 100 for light). The effect of all the factors on $L^{*}$ value of apples was not significant but a slight decrease in $L^{*}$ value was observed in the RF treated apples. A change in hue angle $\left(h^{\circ}\right)$ signified the shift toward yellow or red within the yellow to red quadrant. There was a significant effect of wax coating and storage time on the hue angle. The mean value of hue angle significantly increased from 21.45 measured at the 7 th day of storage to 23.45 measured at the 30th day after treatments. In comparison to control apples there was no significant difference in hue angle for all the heat-treated apples except for the treatment of apples at $48^{\circ} \mathrm{C}$ for $20 \mathrm{~min}$ (Table 2). Chroma is the quality that distinguishes a pure hue from gray shade. The values of chroma of heat-treated apples were significantly lower than that of the control apples. The effects of wax coating and storage time on the hue angle were also significant.

The effect of RF treatments on $L^{*}$ values of pulp was significant (Table 2). A shift of the $L^{*}$ value toward the darker side, means lower $L^{*}$ values, suggesting a conversion of starch into fruit sugars over the storage time. The RF heat treatments caused a significant decrease in $L^{*}$ values of the pulp of treated fruit in comparison with control fruit. The values of hue angles were significantly lower in the apples subjected to the heat treatment in comparison with values of control apples (Table 2). The effect of the wax coating and storage time was not significant, however an interaction between these factors was significant. The value of chroma for heat-treated apples was significantly altered by wax coating and thermal treatments. However, there was a significant interaction among wax coating, storage time and treatment, and the main effects of the individual factor could not be separated. Therefore a trend of the pulp color change induced by heat treatments could not be determined.

\subsubsection{Titrable acidity and TSS}

The average values for TSS $(\%)$ and TA $(\mathrm{g} / 100 \mathrm{ml})$ before treatment were $12.80 \pm 0.57 \%$ and $0.52 \pm 0.04(\mathrm{~g} / 100 \mathrm{ml})$, respectively. No significant differences were observed with TSS and TA values for all of the treatments as compared to the controls stored for 7 and 30 days at $4{ }^{\circ} \mathrm{C}$ (data not shown).

\section{Conclusions}

The hot water assisted RF treatments provided a very uniform heating over the entire cross section of apples. Heat treatments at $48^{\circ} \mathrm{C}$ for at least a $15 \mathrm{~min}$ holding period resulted in $100 \%$ mortality of fifth-instar codling moth in 'Red Delicious' apples. There was no significant effect of RF heat treatments on titratable acidity or soluble solids contents of apples even after 30 day storage at $4{ }^{\circ} \mathrm{C}$. Although the RF heat treatments had a significant effect on firmness, weight loss, and peel and pulp color, the changes were not undesirable. The low weight loss and retaining of firmness in heat treated apples might be considered as beneficial in view of long term storage of apples. However further long term storage studies are required to substantiate this conclusion.

The conceptual treatment design in this study can be potentially used in developing commercial water assisted RF heating processes for insect control in apples. This research will be helpful for developing an effective quarantine treatment for industrial applications. The numbers of larvae in the treatments were, however, too low to demonstrate treatment efficacy at the probit-9 level (99.9968\% mortality). More studies, namely long term storage, sensory evaluation, flavor analysis, feasibility and large scale efficacy demonstration, are needed to draw a definite conclusion about the applicability of the RF energy in conjunction with conventional hot water treatments.

\section{Acknowledgments}

This research was supported by grants from USDA-IFAFS (00-52103-9656) and USDA-NRI (05-35503-16223) programs, and from Washington State University IMPACT Center. We thank Millie Heidt and Michele Watkins (USDAARS, Wapato, WA) for technical assistance.

\section{References}

Andreuccetti, D., Bini, M., Ignesti, A., Gambetta, A., Olmi, R., 1994. Microwave destruction of woodworms. J. Microwave Power Electrom. Energy 29, 153-160.

Armstrong, J.W., 1994. Heat and cold treatments. In: Paull, R.E., Armstrong, J.W. (Eds.), Insect Pests and Fresh Horticultural Products: Treatments and Responses. CAB International, Wallingford, UK, pp. 103-119.

Birla, S.L., Wang, S., Tang, J., Fellman, J., Mattinson, D., Lurie, S., 2005. Quality of oranges as affected by potential radio frequency heat treatments against Mediterranean fruit flies. Postharvest Biol. Technol. 38, 66-79.

Birla, S.L., Wang, S., Tang, J., Hallman, G., 2004. Improving heating uniformity of fresh fruit in radio frequency treatments for pest control. Postharvest Biol. Technol. 33, 205-217.

Feng, X., Hansen, J.D., Biasi, B., Mitcham, E.J., 2004. Use of hot water treatment to control codling moths in harvested California 'Bing' sweet cherries. Postharvest Biol. Technol. 31, 41-49.

Guance, A.P., Madsen, H.F., McMullen, R.D., 1981. Fumigation with methyl bromide to kill larvae and eggs of codling moth in Lambert cherries. J. Econ. Entomol. 74, 154-157.

Hallman, G.J., Sharp, J.L., 1994. Radio frequency heat treatments. In: Sharp, J.L., Hallman, G.J. (Eds.), Quarantine Treatments for Pests of Food Plants. Westview Press, San Francisco, CA, pp. 165-170.

Hansen, J.D., Drake, S.R., Moffitt, H.R., Robertson, J.L., Albano, D.J., Heidt, M.L., 2000. A two-component quarantine treatment for postharvest control of codling moth on apple cultivars intended for export to Japan and Korea. Hortic. Technol. 10, 186-194.

Hansen, J., Wang, S., Tang, J., 2004. A cumulated lethal time model to evaluate efficacy of heat treatments for codling moth Cydia pomonella (L.) (Lepidoptera: Tortricidae) in cherries. Postharvest Biol. Technol. 33, 309-317.

Hayes, C.F., Chingon, H.T.G., Nitta, F.A., Wang, W.J., 1984. Temperature control as an alternative to ethylene dibromide fumigation for the control of fruit flies (Diptera: Tephritidae) in papaya. J. Econ. Entomol. 77, 683-686. 
Ikediala, J.N., Tang, J., Hansen, J., Drake, S.R., Wang, S., 2002. Quarantine treatment of fruits using radio frequency energy and an ionicwater-immersion technique. Postharvest Biol. Technol. 24, 25-37.

Johnson, J.A., Valero, K.A., Wang, S., Tang, J., 2004. Thermal death kinetics of red flour beetle, Tribolium castaneum (Coleoptera: Tenebrionidae). J. Econ. Entomol. 97, 1868-1873.

Mitcham, E.J., Veltman, R.H., Feng, X., de Castro, E., Johnson, J.A., Simpson, T.L., Biasi, W.V., Wang, S., Tang, J., 2004. Application of radio frequency treatments to control insects in in-shell walnuts. Postharvest Biol. Technol. 33, 93-100.

Moffitt, H.R., Drake, S.R., Toba, H.H., Hartsell, P.L., 1992. Comparative efficacy of methyl bromide against codling moth (Lepidoptera: Tortricidae) larvae in Bing and Rainier cherries and confirmation of efficacy of a quarantine treatment for Rainier cherries. J. Econ. Entomol. 85, 1855-1858.

Nelson, S.O., 1996. Review and assessment of radio-frequency and microwave energy for stored-grain insect control. Trans. ASAE 39, 1475-1484.

Shellie, K.C., Mangan, R.L., 2000. Postharvest disinfestation heat treatments: response of fruit and fruit fly larvae to different heating media. Postharvest Biol. Technol. 21, 51-60.

Tang, J., Ikediala, J.N., Wang, S., Hansen, J.D., Cavalieri, R.P., 2000. High-temperature-short-time thermal quarantine methods. Postharvest Biol. Technol. 21, 129-145.

Toba, H.H., Howell, J.F., 1991. An improved system for mass-rearing codling moths. J. Entomol. Soc. B.C. 88, 22-27.

USDA-APHIS-PPQ, 2002. Treatment manual: interim edition. U.S. Department of Agriculture, Animal Plant Health Inspection Service, Plant Protection Quarantine, Riverdale, MD.

USDA-NASS, 2004. Agricultural Statistics, 2004. Statistics of Fruits, Tree Nuts and Horticultural Specialties. U.S. Department of Agriculture, Nat. Agric. Stat. Serv., Washington, D.C. (chapter V).
[USEPA] United States Environmental Protection Agency, 1998. Reregistration Eligibility Decision. Aluminum and Magnesium Phosphide. Cases 0025 and 0645. Office of Pesticide Programs, Special Review and Reregistration Division. Agricultural Statistics. Washington, D.C.

Wang, S., Ikediala, J.N., Tang, J., Hansen, J.D., Mitcham, E., Mao, R., Swanson, B., 2001a. Radio frequency treatments to control codling moth in in-shell walnuts. Postharvest Biol. Technol. 22, 29-38.

Wang, S., Tang, J., Cavalieri, R.P., 2001b. Modeling fruit internal heating rates for hot air and hot water treatments. Postharvest Biol. Technol. 22, 257-270.

Wang, S., Ikediala, J.N., Tang, J., Hansen, J.D., 2002a. Thermal death kinetics and heating rate effects for fifth-instar Cydia pomonella (L.) (Lepidoptera: Tortricicae). J. Stored Prod. Res. 38, 441-453.

Wang, S., Tang, J., Johnson, J.A., Mitcham, E., Hansen, J.D., Cavalieri, R.P., Bower, J., Biasi, B., 2002b. Process protocols based on radio frequency energy to control field and storage pests in in-shell walnuts. Postharvest Biol. Technol. 26, 265-273.

Wang, S., Tang, J., Johnson, J.A., Mitcham, E., Hansen, J.D., Hallman, G., Drake, S.R., Wang, Y., 2003. Dielectric properties of fruits and insect pests as related to radio frequency and microwave treatments. Biosyst. Eng. 85, 201-212.

Wang, S., Yin, X., Tang, J., Hansen, J., 2004. Thermal resistance of different life stages of codling moth (Lepidoptera: Tortricidae). J. Stored Prod. Res. 40, 565-574.

Yokoyama, V.Y., Miller, G.T., Dowell, R.V., 1991. Response of codling moth (Lepidoptera: Tortricidae) to high temperature, a potential quarantine treatment for exported commodities. J. Econ. Entomol. 84, 528-531.

Yokoyama, V.Y., Miller, G.T., Hartsell, P.L., 1990. Evaluation of a methyl bromide quarantine treatment to control codling moth (Lepidoptera: Tortricidae) on nectarine cultivates proposed for export to Japan. J. Econ. Entomol. 83, 466-471. 